\title{
ENVIRONMENTAL IMPACTS OF LANDFILL COVERING BY USE OF INDUSTRIAL BY-PRODUCTS
}

\author{
Frida Veibäck \\ Lena Johansson Westholm. \\ Mälardalen University, Sweden
}

\begin{abstract}
Since the introduction of an EC-directive on stronger demands on covering and lining of landfills, the Swedish Parliament has adopted new legislation on waste deposition. Within a near future, a large number of landfills in Sweden have to be closed down due to these stronger demands. Covering of landfills has traditionally been carried out with till as covering material. The use of till causes depletion of a natural resource and in addition, high costs for transportation might arise. Alternative materials have thus been sought for. Two potential materials are sludge and ash. Their behaviour with regard to leaching is not very well known and the focus of this work is to further investigate this issue. A pilotscale area on a closed-down part of the Gryta landfill site in Västerås, Sweden; was partly covered with composted sewage sludge mixed with mineral soil, partly with ash. The aim was to find out whether the leachate from the covered areas had to be subject for further treatment before being discharged into the recipient. The leachate was analysed for nitrogen and phosphorus. The results from the first three months of the experiment showed high concentrations of both nitrogen and phosphorus in the leachate, probably due to a washing effect. It is expected that the nutrient concentrations will decrease in the future when the content of nutrients in the covering materials have been washed out and when vegetation has been established. Further investigations of the leachate will confirm this. Based on these findings and the fact that the materials fulfil other requirements for covering materials, it was concluded that both sludges and ashes could be regarded as suitable materials for a sustainable landfill covering. Further investigations on the subject are however suggested.
\end{abstract}

\section{KEYWORDS}

ash, composted sludge, fill material, Gryta landfill site, nitrogen, phosphorus 


\section{INTRODUCTION}

The Swedish Parliament has adopted new legislation on waste deposition since the introduction of an EC-directive for more stringent demands on lining and covering of landfills. Due to the new directive, a large number of landfills in Sweden are supposed to be closed down in the next few years. These landfills have to be properly covered in order to sustain for many decades. The requirements for landfills (class 1 and 2) are that the generation of leachate do not exceed 5 and $50 \mathrm{l} /\left(\mathrm{m}^{2}\right.$.year) respectively and, that the $\mathrm{k}_{\mathrm{f}}$ is less than $10^{-9}$ in order to prevent water to penetrate the cover over a period of 50 years.

Covering of landfills has generally been carried out using natural materials, for instance clay and till, in the different covering layers [1]. There is however a shortage of suitable natural materials, especially in urban areas, implying that high costs might arise from transportation of these materials to landfills to be covered [2]. Another disadvantage using natural materials is that natural resources are depleted when these are quarried. Therefore, alternative materials that can substitute these are of interest. Industrial byproducts belong to a category of materials that has attracted attention in recent years. Two materials, available in surplus in urban areas, are sludge and ashes, e.g. fly ashes and bottom ashes. Both these materials have been tested as covering materials in Sweden as well as in other countries with promising results $[3,4,2,5]$.

The investigations have in most cases been focused on the hydraulic properties of the materials and results show that the materials are suitable for covering purposes $[5,6]$. Less attention has been paid to the environmental effects of these materials when used as liners or protection layers. It is of importance to find out whether unwanted substances such as metals or nutrient are leachable from the materials, since the generated leachate might need treatment before being discharged into the recipient. Johansson [7] showed for instance that ashes contain organic material that can be leached. The amounts of PAHs in ashes varied according to the study, and in some cases the leached PAHs exceeded the Swedish generic guidelines for PAHs in soil [7]. Also sludge contains substances hazardous to the environment [8]. Except for nutrients, the sludge might contain other pollutants such as heavy metals due to the fact that polluted waters others than domestic wastewaters are transferred to municipal wastewater treatment plants.

Leaching of nutrients from ashes and sludges has not been investigated in the same extent; thus it is an important question to address. The aim with the present investigation was there-fore to study the leaching of nutrients, e.g. phosphorus (P) and nitrogen $(N)$ from ashes and sludges mixed with fill material in the initial phase of a field trial at the Gryta landfill site in Västerås, Sweden.

\section{MATERIALS AND METHODS}

\subsection{Site description}

The Gryta landfill north of Västerås is one of the landfills that have to be closed down before 2008 due to the new legislation concerning more stringent demands on lining and top covering. The landfill site is run and operated by the waste company Västmanlands 
KALMAR ECO-TECH'03

Bioremediation and Leachate Treatment

KALMAR, SWEDEN, November 25-27, 2003

Avfalls-aktiebolag (Vafab). There is one landfill at the site. The landfill consists of two parts, one is still in operation, and the other one was closed down in 1991. Domestic and industrial wastes as well as sludge have been deposited at the landfill without sorting.

A part of the old landfill has since the end of 2002 been subject of a pilot-scale study with regard to the investigation of different industrial by-products as covering materials. One of the aims with the project was to investigate the leachate from different layers of the covering. For this purpose, the pilot-scale area was divided into two equally large test areas, each with an area of $500 \mathrm{~m}^{2}$ and a height: length ratio of 1:10. The foundation layer in the first test area was composed of a mixture (1:1) of fly ash from the incineration plant in Västerås (combustion of coal/peat) and bottom ash from the Högdalen incineration plant (combustion of domestic wastes). The corresponding material in the second area was a mixture of fly ash from the

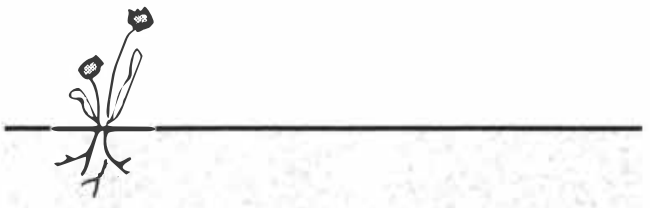

neter 1

leter 2

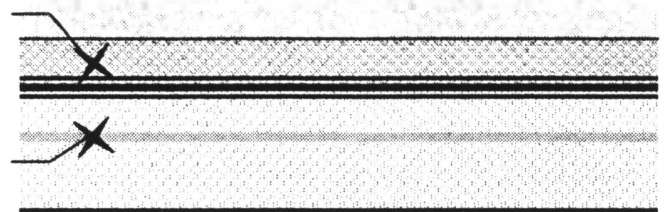

Vegetation

Protection layer, $0.1 \mathrm{~m}$

Drainage layer, $0.3 \mathrm{~m}$

Impermeable layer; $0.1 \mathrm{~m}$

Synthetic geomembrane (LLDPE)

Foundation layer, $0.6 \mathrm{~m}$

Figure 1. Principle design of the final covering at the Gryta landfill site

incineration plant in Västerås (combustion of biofuel/wood) and bottom ash from the Högdalen incineration plant (combustion of domestic wastes). Also in this case, the ratio was 1:1. A synthetic geomembrane (LLDPE) was placed in the foundation layer in order to collect water that possibly would percolate through the impermeable layer (see Figure 1). On top of the foundation layers, an impermeable layer consisting of a clay geomembrane (bentonite) and stone powder was placed. A drainage layer covered the impermeable layer and as protection layer, a mixture of composted sewage sludge and fill material was used.

Equipment for collection of percolated water was installed in both test areas. In each test area, one lysimeter was placed immediately below the protection layer, and one in the foundation layer, see Figure 1. Percolated water from the lysimeters was separately transferred to a near-by well, common for the two test areas. In the well, different 
KALMAR ECO-TECH'03

Bioremediation and Leachate Treatment

KALMAR, SWEDEN, November 25-27, 2003

containers were placed in order to collect the water from each lysimeter. The containers were graded in order to enable measurements of the water volume.

\subsection{Sampling and analyses}

The sampling period started on April 15, and ended on June 3. Samples of the percolated water were taken once a week. The water samples were pumped from the well into plastic bottles and transferred directly to the laboratory where they were analysed for total-P, total- $\mathrm{N}, \mathrm{NO}_{3}-\mathrm{N}, \mathrm{NO}_{2}-\mathrm{N}$ and $\mathrm{NH}_{4}-\mathrm{N}$. The samples were analysed in duplicate, two were non-filtrated, two were filtrated $(0.45 \mu)$. The analyses were carried out by means of $\mathrm{Dr}$ Lange photometer (Isis 9000). To determine concentrations of the mentioned nutrient fractions, Cuvette-Tests were used in accordance with standard instructions.

\section{RESULTS}

During the experimental period, percolated water could only be sampled from the uppermost lysimeters due to lack of water in the lower ones. The results from the investigation are presented in Table 1.

Table 1. Concentrations of phosphorus and nitrogen in the drainage water from the protection layer

\begin{tabular}{|c|c|c|c|c|c|c|c|c|c|c|}
\hline \multirow[t]{2}{*}{ Date } & \multicolumn{2}{|c|}{$\begin{array}{r}\text { Total-P } \\
(\mathrm{mg} / \mathbf{l})\end{array}$} & \multicolumn{2}{|c|}{$\begin{array}{r}\text { Total-N } \\
(\mathrm{mg} / \mathbf{l})\end{array}$} & \multicolumn{2}{|c|}{$\begin{array}{r}\mathrm{NH}_{4}-\mathbf{N} \\
(\mathbf{m g} / \mathbf{l})\end{array}$} & \multicolumn{2}{|c|}{$\begin{array}{r}\mathrm{NO}_{3}-\mathrm{N} \\
(\mathrm{mg} / \mathrm{l})\end{array}$} & \multicolumn{2}{|c|}{$\mathrm{NO}_{2}-\mathrm{N}(\mathrm{mg} /)$} \\
\hline & nf & $\mathbf{f}$ & nf & f & nf & $\mathbf{f}$ & nf & f & nf & f \\
\hline April 15 & 2.07 & - & 286 & - & 10.3 & - & 2 & - & - & - \\
\hline April 22 & $<0.1$ & - & 368 & - & 9.2 & - & 285 & - & - & - \\
\hline April 29 & 0.19 & - & 558 & - & 18.1 & - & 505 & - & - & - \\
\hline May 6 & 0.50 & 0.50 & 339 & 464 & - & 69.0 & 230 & 344 & 1.88 & 0.74 \\
\hline May 13 & 0.36 & 0.34 & 466 & 479 & 44.9 & 44.2 & 369 & 374 & 0.56 & 0.57 \\
\hline May 20 & 0.28 & 0.26 & 502 & 498 & 29.6 & 19.6 & 391 & 385 & 0.62 & 0.64 \\
\hline May 27 & 0.27 & 0.26 & 487 & 480 & 52.6 & 51.6 & 408 & 402 & 0.77 & 0.72 \\
\hline June 3 & 0.23 & 0.21 & 509 & 513 & 17.4 & 17.4 & 445 & 446 & 1.88 & 1.82 \\
\hline
\end{tabular}

$\mathrm{f}=$ filtrated, $\mathrm{nf}=$ non filtrated

The results show that the concentrations of total-P were found in the range $0.1-2.07 \mathrm{mg} / 1$ for non-filtrated samples and $0.21-0.50$ for the filtrated samples. The P-concentrations in the non-filtrated and filtrated samples showed good agreement at all sampling occasions when compared indicating that the $\mathrm{P}$ was not particulate bound.

The concentrations of total- $\mathrm{N}$ varied between $286-558 \mathrm{mg} / \mathrm{l}$ for the non-filtrated samples and $464-513 \mathrm{mg} / \mathrm{l}$ for the filtrated samples. Again, the concentrations in the non-filtrated and filtrated samples showed good agreement except for May 6, when the $\mathrm{N}$ concentration in the filtrated sample was much higher than in the non-filtrated sample. 
The figures for ammonia- $\mathrm{N}$ varied between $9.2-52.6 \mathrm{mg} / \mathrm{l}$. The figures show the same pattern as for total-P and total-N, a good agreement with non-filtrated and filtrated samples. At one occasion, May 20, the concentrations differ.

The concentrations of $\mathrm{NO}_{3}-\mathrm{N}$ varied between $2-505 \mathrm{mg} / \mathrm{l}$ for the non-filtrated samples and between $344-446 \mathrm{mg} / \mathrm{l}$ for the filtrated samples. The concentrations for the nonfiltrated and filtrated samples showed a good agreement also in this case, with exception for May 6, when the $\mathrm{NO}_{3}-\mathrm{N}$ concentration was higher in the filtrated sample.

The concentrations of $\mathrm{NO}_{2}-\mathrm{N}$ varied between $0.56-1.88 \mathrm{mg} / \mathrm{l}$ for the non-filtrated samples and between $0.57-1.82 \mathrm{mg} / \mathrm{l}$ for the filtrated samples. The differently treated samples show good agreement also for this $\mathrm{N}$-fraction with exception for the sampling occasion on May 6 when the $\mathrm{NO}_{2}-\mathrm{N}$ concentration was much higher in the non-filtrated sample.

\section{DISCUSSION AND CONCLUSIONS}

For the purpose of this survey, water from the final covering has been collected and analysed during eight weeks. This is a limited period of time, indicating that conclusions about the final covering in toto cannot be drawn. The study only concerns the initial phase of the final covering, when vegetation was not yet established on the surface, when precipitation built in to the covering started to come out; e.g. when the conditions for leachate therefore were the worst possible.

The design of the final covering at the Gryta landfill site is expected to be safe. The protection layer is supposed to have good water holding properties, due to the structure and content of organic matter of the composted sewage sludge mixed with fill from nearby building sites. One of the main ideas with this type of top cover is that vegetation will establish on the surface and increase the water transpiration; thus reducing the production of leachate and minimizing the pressure on the liner.

The pilot-scale experiment showed that only very small amounts of water could be collected from the lower lysimeters; e.g. in too small quantities allowing for analysis. Water in sufficient quantities could on the other hand be collected from the uppermost lysimeters. There are two possible sources of this water. The first one is precipitation that has percolated through the protection layer, the second is precipitation built into the system during the construction. During the experimental period, the precipitation was approximately $100 \mathrm{~mm}$ [9]. In spite of this, it cannot be concluded that water has percolated through the protection layer due to the water holding properties of the top material. The percolated water is most probably originating from snow and ice being included in the construction of the covering system. The covering system was constructed during the winter of 2002 and it snowed during this period. The percolated water collected is therefore likely to originate from melting of the included precipitation. If this is the case, the results indicate that the final covering is fulfilling its task, namely preventing water from percolating through the layers reaching the waste and produce leachate. This is also supported by the fact that no water has so far percolated through the impermeable layer [10]. 
The percolated water did however contain nutrients. During the sampling period, the nutrient content in the percolated water was in relation to regional agricultural runoff in the same range. Less total-P was leaking from the final covering than from agricultural land during the experimental period [9]. Total-N losses from the final covering were 10 times higher than losses from agricultural land during the initial phase. This indicates that the problem with leachate from the final covering is a question of N-leakage Analysis of the water shows that most of this N-leaking is in form of nitrate.

Another question that arises, is for how long these $\mathrm{N}$-concentrations in the percolated water will remain? According to Sundberg et al. [2], the amounts of leachable nutrients are higher during the first years but are expected to decline over time. Experiments with composted sewage sludge mixed with mineral soil in the same proportions have been conducted in Austria. These results also shows a reduction of approximately $60 \%$ in nitrate concentrations in percolated water over the first six months of the experimental period [11].

Eutrophication is the most considerable environmental issue that the final covering contributes to by its release of nitrogen. Phosphorus is the limiting nutrient in the recipient, lake Mälaren, but the leakage of phosphorus is small. The Gryta landfill site discharge a total of 40 tonnes of nitrogen per year. This water volume is transferred to the municipal sewage treatment plant where nitrogen concentrations are reduced by approximately $50 \%$. This means that the release of nitrogen into lake Mälaren caused by Gryta landfill is $450 \mathrm{~kg} \mathrm{~N}$ per year. The final covering would during one year release at maximum $150 \mathrm{~kg} \mathrm{~N}$. This figure is very approximate and most likely too high since it is based on measurements during the implementation phase. During this period the covering surface has not been covered with vegetation, which means that not only concentrations but also amounts of water would in fact decrease over time.

For the future, it is of importance to monitor the cover system in order to investigate the amounts of water that possibly will percolate through the different layers indicating whether the sealing is sufficiently constructed. It is also of importance to continue the monitoring of the nutrient concentrations from the protection layer in order to find out if the water has to be treated or not before being discharged into the recipient. In fact, there is a monitoring programme running for this purpose. Samples are collected weekly, frozen, and analysed monthly as a composite sample. It is suggested that this monitoring programme will last during the following number of years.

\section{ACKNOWLEDGEMENTS}

The authors want to thank Anna Thuresson at Västmanlands Avfallsaktiebolag for valuable discussions. 


\section{REFERENCES}

[1] Lundgren, T., 1995. Sluttäckning av avfallsupplag - krav, material, utförande och kontroll. Naturvårdsverket rapport 4474 (in Swedish).

[2] Sundberg, J., Carling, M., Ländell, M. and Svensson, B., 2002. Täckning av deponier med blandning av avloppsslam och aska - erfarenheter, beständighet och andra egen-skaper. Renhållningsverksföreningen, rapport 2002:18 (in Swedish).

[3] Svenska Renhållningsverksföreningen, 2003. Försök med tätskikt av blandningar av slam från avloppsreningsverk, aska, grus och fibermassa från pappersbruk. RVF:s utvecklingssatsning deponering, rapport nr 32003 (in Swedish).

[4] Tham, G. Andreas, L. \& Lagerkvist, A., 2003. Use of ashes in landfill covers. Proceedings Sardinia 2003, Ninth International Waste Management and Landfill Symposium, S. Margherita di Pula, Cagliari, Italy; 6-10 October 2003.

[5] Kämpf, M., Holfelder, T. and Montenegro, H., 2001. Material selection for capillary barriers. In Proceedings Sardinia 2001, $8^{\text {th }}$ International Waste Management and Landfill Symposium, S. Margherita di Pula, Cagliari, Italy; 1-5 October 2001, volume III, pp 325-334.

[6] Wagner, J.-F. \& Schnatmeyer, C., 2002. Test field study of different cover sealing systems for industrial dumps and polluted sites. Applied Clay Science 21:99-116.

[7] Johansson, I., 2003. Characterisation of organic materials from incineration residues. $\mathrm{PhD}$ Thesis, Man-Technology-Environment Research Centre, Department of Natural Sciences, Örebro University. University Library, Örebro, Sweden.

[8] Monica Odlare, Department of Public Technology, Mälardalen University, personal communication.

[9] Veibäck, F., 2003. Miljöpåverkan vid deponitäckning - Användning av restprodukter för sluttäckning av Gryta deponi. Master thesis 2003-053, Department of Public Technology, Mälardalen University, Västerås (in Swedish).

[10] Anna Thuresson, Västmanlands Avfallsaktiebolag, personal communication.

[11] Huber-Humer, M., Gomiscek, T. and Lechner, P., 2001. Substrate and design of an alternative landfill cover to enhance methane oxidation and minimise the leachate production. Department of Waste Management, University fûr Bodenkultur, Vienna, Austria. 